\title{
Terapi Relaksasi (Napas Dalam) dalam Mengurangi Nyeri Persalinan
}

\section{Relaxation Therapy (Inside Breathing) In Reducing Labor}

\author{
Juistira Safitri ${ }^{1}$, Sunarsih ${ }^{1}$, Dewi Yuliasari ${ }^{1}$ \\ ${ }^{1}$ Program Studi Kebidanan, Universitas Malahayati, Bandar Lampung, Indonesia \\ *Korespondensi penulis: sunarsih@malahayati.ac.id
}

Penyerahan: 25-08-2020, Perbaikan: 22-09-2020, Diterima: 26-09-2020

\begin{abstract}
The problem that most often arises in women who give birth is labour pain. If not resolved, it will cause anxiety, fear and stress on the mother, which will increase the intensity of the pain felt. Pain during labour accompanied by fear will slow down the labour process. Labour pain cause hyperventilation, respiratory alkalosis, vasoconstriction of blood vessels in the uterus and acidosis in the fetus, and also increase oxygen consumption. Increasing noradrenaline will reduce blood to the placenta and decrease uterine contractions, thus interfering with the safety of the mother and fetus and the success of vaginal labour. The research objective was to determine the effect of relaxation therapy (deep breathing) in reducing labour pain. It used quantitative research with a quasi-experimental approach. Purposive sampling was used as a strategy. The target in the study of all women at the time of birth opening $4-7 \mathrm{~cm}$, the sample was 30 people. The research has been carried out in the Independent Practice of Midwife D Bandar Lampung City on 16 February - 30 June 2019. Data collection using observation sheets, analyzing data in bivariate with $t$-test. The result of the study showed that the average labour pain before relaxation therapy (deep breath) was 6,7 with a standard deviation of 0.8 . The average labour pain after being given relaxation therapy (deep breath) was 4.3 with a standard deviation of 0.9 , and p-value $<0.001$. There is an effect of relaxation therapy (deep breathing) in reducing labour pain. To midwives to be able to provide Non- pharmacological therapy in reducing labour pain with relaxation therapy (deep breathing).
\end{abstract}

Keywords: Deep Breathing, Pain, Labor.

\section{ABSTRAK}

Masalah yang paling sering muncul pada ibu bersalin adalah nyeri persalinan. Apabila tidak di atasi akan menimbulkan kecemasan, ketakutan serta stress pada ibu yang akan meningkatkan lagi intensitas nyeri yang dirasakan. Nyeri selama proses persalinan yang disertai dengan ketakutan akan memperlambat proses persalinan. Nyeri persalinan akan menimbulkan hiperventilasi, meningkatkan konsumsi oksigen, menimbulkan alkalosis respiratorik, vasokontriksi pembuluh darah dalam uterus dan asidosis pada fetus. Meningkatkan noradrenalin akan menurunkan darah ke plasenta dan menurunkan kontraksi uterus sehingga mengganggu keselamatan ibu dan fetus dan keberhasilan partus pervaginam. Tujuan penelitian untuk mengetahui pengaruh terapi relaksasi (napas dalam) dalam mengurangi nyeri persalinan. Jenis penelitia kuantitatif dengan pendekatan quasi eksperimen. Teknik sampling dengan cara purposive sampling. Sasaran dalam penelitian seluruh ibu bersalin kala 1 pembukaan $4-7 \mathrm{~cm}$, sampel

Jurnal Dunia Kesmas, Vol. 9 No. 3, Juli 2020, hal. 365-370

365

ISSN 2301-6604 (Print), ISSN 2549-3485 (Online)

http://ejurnalmalahayati.ac.id/index.php/duniakesmas/index 
berjumlah 30 orang. Tempat penelitian telah dilaksanakan di Praktik Mandiri Bidan di Kota Bandar Lampung pada 16 Februari - 30 Juni 2019. Pengumpulan data menggunakan lembar observasi, analisa data bivariate dengan uji t. Hasil penelitian rata- rata nyeri persalinan sebelum diberikan terapi relaksasi (nafas dalam) adalah 6.7 dengan standar deviasi 0.8. Rata - rata nyeri persalinan setelah diberikan terapi relaksasi (napas dalam) adalah 4.3 dengan standar deviasi 0.9 , dan p-value $<0.001$. Ada pengaruh terapi relaksasi (napas dalam) dalam mengurangi nyeri persalinan. Kepada bidan untuk dapat memberikan terapi norfarmakologi dalam mengurangi nyeri persalinan dengan terapi relaksasi (napas dalam).

Kata kunci: Tingkat Kecemasan, Nyeri Persalinan.

\section{PENDAHULUAN}

Persalinan merupakan proses membuka dan menipisnya serviks dan janin turun kedalam jalan lahir kemudian berakhir dengan pengeluaran bayi yang cukup bulan atau hampir cukup bulan atau dapat hidup diluar kandungan. Persalinan dimulai (inpartu) sejak uterus berkontraksi dan menyebabkan perubahan pada serviks (membuka dan menipis) kemudian berakhir dengan lahirnya plasenta secara lengkap. (Mutmainah, A. U., Johan, H., \&Llyod, S. S. 2017)

Masalah yang paling sering muncul pada ibu bersalin adalah nyeri persalinan. Apabila masalah nyeri tidak di atasi akan menimbulkan kecemasan, ketakutan serta stress pada ibu yang akan meningkatkan lagi intensitas nyeri yang dirasakan. Nyeri selama proses persalinan yang disertai dengan ketakutan akan memperlambat proses persalinan. Nyeri persalinan akan menimbulkan hiperventilasi, meningkatkan konsumsi oksigen, menimbulkan alkalosis respiratorik, vasokontriksi pembuluh darah dalam uterus dan asidosis pada fetus. Meningkatkan noradrenalin akan menurunkan darah ke plasenta dan menurunkan kontraksi uterus sehingga mengganggu keselamatan ibu dan fetus dan keberhasilan partus pervaginam. (Heni Setyowati, E. R., Kp, S., \&Kes, M. 2018)

Tatalaksana nyeri persalinan dapat berupa tatalaksana farmakologis dan non farmakologis. Tatalaksana non farmakologis pada proses persalinan dapat dilakukan dengan menggunakan teknik relaksasi, pernapasan yang teratur, dan berbagai tindakan kenyaman dan posisi tubuh lainnya. Teknik tersebut dapat membantu mengendalikan nyeri dan stress pada sebagian besar persalinan. Teknik ini juga mendorong perkembangan persalinan dan membuat ibu bersalin secara pribadi merasa lebih mampu menghadapi pengalaman tersebut (Simkin, P., Whalley, J., \& Keppler, A. 2010). Teknik relaksasi digunakan untuk membantu memberikan rasa nyaman pada ibu.(Damayanti, I. P., Maita, L., Triana, A., \& Afni, R. 2012). Secara psikologis relaksasi yang berhasil menghasilkan perasaan sehat, tenang dan damai, suatu perasaan berada dalam kendalai, serta penurunan dalam ketegangan dan kegelisahan. Secara fisiologis relaksasi menghasilkan penurunan tekanan darah, pernafasan dan 
detak jantung yang seharusnya muncul (Saleh, L. M. (2019).

Praktik Mandiri Bidan (PMB) D merupakan salah satu PMB yang terletak di Bandar Lampung. Pada Pada kasus, dan pada tahun 2018 jumlah persalinan sebanyak 557 kelahiran dan yang mengalami komplikasi sebanyak $62(11,13 \%)$ kasus. Diantara komplikasi tersebut ada yang mengalami kontraksi rahim yang tidak terkoordinasi dengan baik karena nyeri yang dirasakan oleh ibu saat persalinan.

Hasil observasi yang dilakukan di PMB D pada 16 - 17 februari 2019 di dapatkan 5 ibubersalin, dan terdapat $1(20 \%)$ ibu bersalin dapat menahan rasa nyeri yang dialaminya, dan sebanyak 4 (80\%) ibutidakdapatmenahan rasa nyerihinggaberteriak. Studi pendahuluan dihasilkan dari 5 ibu bersalin yang mengalami nyeri, terdapat 3 (60\%) ibu merasa nyaman setelah dilakukan terapi relaksasi napas dalam.

\section{METODE PENELITIAN}

Jenis penelitian ini adalah kuantitatif (metode yang berlandaskan pada filsafat positifisme) yang digunakan pada populasi atau sample tertentu(Sugiono, S. 2016). Rancangan yang digunakanyaitu rancangan quasi eksperimen dan pendekatan one group pretest postest yaitu dimana peneliti melakukan observasi pertama (pre- tahun tahun 2017 sampai bulan November terdapat sebanyak 592 kelahiran dan yang mengalami komplikasi.

test) lalu kemudian peneliti memberi perlakuan dan melihan perubahanperubahan yang terjadi setelahnya (post-test) (Agus, R. 2011). Penelitian telah dilakukan sejak tanggal 16 Februari - 30 Juni 2019. Populasi dalam penelitian ini adalah seluruh ibu dalam proses persalinan kala I di Praktik Mandiri Bidan D Kota Bandar Lampung tahun 2019 rata - rata 39 orang. Pengambilan sampel dengan teknik purposive sampling dan didapat 30 ibu bersalin yang memenuhi kriteria yaitu; ibu bersalin yang kooperatif selama penelitian, tidak mengkonsumsi obat pereda nyeri, ibu bersalin tanpa komplikasi persalinan.

Variabel independen dalam penelitian ini adalah relaksasi napas dalam sedangkan variabel dependen yaitu nyeri persalinan. Data skala nyeri dikumpulkan dengan menggunakan lembar observasi skala nyeri Visual Analog Scale(VAS). Analisa univariat dan bivariat dilakukan dengan menggunakan aplikasi komputer, analisa univariat bertujuan untuk melihat distribusi frekuensi sedangkan analisa biavariat bertujuan untuk menguji hipotesis dengan menggunakan uji t-test. 


\section{HASIL}

Tabel 1. Distribusi Rata-Rata Tingkat Nyeri pada Ibu Inpartu

\begin{tabular}{ccccccc}
\hline Intensitas Nyeri & Mean & Min & Max & Std.Deviation & n \\
\hline Sebelum terapi relaksasi & 6.7 & 6 & 8 & 0.8 & 30 \\
Sesudah terapi relaksasi & 4.3 & 3 & 6 & 0.9 & 30 \\
\hline
\end{tabular}

Tabel 2. Pengaruh Terapi Relaksasi (napas dalam) dalam Mengurangi
$\begin{array}{ccccccc} \\
\text { Nyeri Persalinan }\end{array}$
\begin{tabular}{|cccccc}
\hline Intensitas Nyeri & Mean & Beda Mean & SD & p-value & $\boldsymbol{n}$ \\
\hline Sebelum terapi relaksasi & 6.7 & 2.4 & 12.7 & $<0,001$ & 30 \\
\hline
\end{tabular}

Berdasarkan tabel 1, diketahui bahwa rata - rata intensitas nyeri sebelum dilakukan terapi relaksasi (napas dalam) adalah 6.7 dengan nilai minimal 6 dan maksimal 8 . serta standar deviasi 0.8 . Sedangkan rata - rata intensitas nyeri setelah dilakukan terapi relaksasi (napas dalam) adalah 4.3 dengan nilai minimal 3 dan maksimal 6 serta standar deviasi 0.9. Berdasarkan tabel 2, diketahui bahwa beda mean intensitas nyeri sebelum dan setelah dilakukan terapi relaksasi (napas dalam) adah 2,400. Hasil uji statistik didapatkan $\mathrm{t}$-test $>\mathrm{t}$ hitung $12,673>p$ value <0.001yang berarti ada pengaruh terapi relaksasi (napas dalam) dalam mengurangi nyeri persalinan.

\section{PEMBAHASAN}

Rata- rata nyeri persalinan sebelum dilakukan terapi relaksasi (napas dalam) adalah 6,7 turun sebesar 2,4 manjadi 4,3. Hasil uji statistik $p$ value < a 0,005 yang berarti ada pengaruh terapi relaksasi (napas dalam) dalam mengurangi nyeri persalinan.

Rasa nyeri saat melahirkan bersifat unik dan berbeda setiap individu, rasa nyeri memiliki karakteristik tertentu yang sama atau bersifat umum. Pengendalian rasa nyeri berhubungan dengan keputusan untuk mengimplementasikan atau memberikan pengendalian nyeri tersebut. Rasa nyeri pada persalinan yang dialami oleh wanita pada saat bersalin disebabkan oleh kontraksi uterus, dilatasi serviks dan distensi perineum, peregangan vagina dan dasar panggul pada akhir kala I dan II. (Widiastini, L. P.2018). Nyeri pada proses persalinan memberikan dampak yang besar pada sistem kardiovaskular dan respirasi. Peningkatan konsentrasi katekolamin dalam plasma yang terjadi selama nyeri persalinan dapat meningkatkan curah jantung ibu dan resistensi pembuluh darah ferifer. Hal ini dapat menyebabkan turunnya perfusi uteroplasenta. Nyeri berkala akibat kontraksi uterus juga dapat menstimulasi system pernapasan dan menyebabkan periode hiperventilasi. Dengan tidak adanya pemberian oksigen yang adekuat, periode hipoventilasi kompensasi antara kontraksi dapat menyebabkan hipoksemia ibu dan janin. Nyeri persalinan yang tidak tertangani akan menyebabkan dekompensasi pada ibu dan janin. Nyeri persalinan yang berat dan tidak teratasi dapat memiliki konsekuensi secara prikologis, termasuk terjadinya depresi dan fikiran negative mengenai peningkatan permintaan 
persalinan secara bedah Caesar. (Rehatta NM, dkk. 2019).

Relaksasi diperbaiki serta dilaksanakan sejak awal persalinan dan kemudian dilanjutkan bersama dengan pemberian dorongan semangat, pendampingan serta pengalihan perhatian. Pengalihan perhatian tersebut dengan konsentrasi pada pernapasan, dilakukan secara lebih intensif ketika kala satu sampai titik puncaknya.(Farrer, H., \& Hartono, A. 2001). Manfaat relaksasi selama persalinan yaitu dapat mengurangi nyeri, relaksasi mengurangi ketegangan dan kelelahan yang mengintensifkan nyeri yang dirasakan selama persalinan. Relaksasi memungkinkan ketersediaan oksigen dalam jumlah maksimal untuk rahim, yang juga mengurangi nyeri, karena otot kerja (yang membuat rahim berkontraksi) menjadi sakit jika kekurangan oksigen. Selain itu relaksasi dapat menenangkan fikiran dan mengurangi stress, tubuh yang relaks membuat pikiran relaks yang akan mengurangi respons stress (Simkin, P., Whalley, J., \& Keppler, A. 2010).

Terdapat penurunan skala nyeri pada ibu bersalin di BPM E pada tahun 2016. Rata - rata skala nyeri sebelum relaksasi adalah 6,90, setelah dilakukan relaksasi skala nyeri turun 1,65 menjadi 5,25. Penghirupan udara yang maksimal mengakibatkan suplai oksigen pada uterus cukup sehingga hal tersebut mengurangi ketegangan pada otot juga mengurangi rasa takut atau kecemasan yang ada pada diri pasien. (Sunarsih, S., \& Ernawati, E. 2017). Releksasi merupakan manajemen yang sangat mudah dilakukan. Pernapasan dengan teknik inhalasi (hirup) dan ekshalasi (hembuskan) yang dilakukan secara teratur dan mendalam akan menghasilkan efek yang baik yaitu menghasilkan oksigen yang cukup. Oksigen yang masuk secara optimal kedalam tubuh dapat merileksasi ketegangan otot dan menenangkan fikiran, mengurangi stress baik fisik maupun emosional sehingga dapat menurunkan intensitas nyeri dan mengurangi kecemasan pada ibu bersalin.

Releksasi sebaiknya dilakukan sejak menjelang persalinan. Ketidakseimbangan hormon persalinan dapat mengakibatkan ketegangan fisik yang berdampak pada meningkatnya kontraksi dan rasa nyeri saat bersalin. Kondisi psikologis dan fikiran yang baik akan memberi respon yang baik bagi tubuh sehingga tubuh bekerja secara maksimal untuk memproduksi hormone oksitosin dan endorphin. Oksitosin sangat diperlukan saat persalinan karena fungsinya dapat meningkatkan kontraksi dan endofrin dapat mengakibatkan perasaan senang dan mengurangi rasa nyeri alami di dalam tubuh. Meskipun mudah dilakukan, namun rileksasi membutuhkan latihan. Rileksasi yang dilakukan sejak menjelang persalinan membuat ibu lebih siap. Begitupun sebaliknya, rileksasi yang dilakukan seketika saat ibu bersalin sudah masuk kala I fase aktif membuat tubuh ibu sulit berkoordinasi dengan baik, sehingga angka keberhasilanya akan rendah. Intensitas nyeri setiap ibu bersalin berbeda - beda. Nyeri dapat dipengaruhi oleh karakteristik pada masing- masing ibu seperti usia, paritas, pengalaman melahirkan serta induksi persalinan. Oleh sebab itu hasil pengukuran skala nyeri 
responden pada penelitian juga berbeda.

\section{SIMPULAN}

Ada pengaruh terapi relaksasi (napas dalam) dalam mengurangi nyeri persalinan ( $p$-value $<0.001)$.

\section{SARAN}

Bagi tenaga kesehatan diharapkan untuk menambah pengetahuan, keterampilan dan memberikan edukasi serta latihan kepada masyarakat tentang penanganan nyeri secara non farmakologi dengan relaksasi (nafas dalam)karena dinilai mudah, murah serta minim efek samping.

\section{DAFTAR PUSTAKA}

Agus, R. (2011). Aplikasi Metodologi penelitian kesehatan. Yogyakarta: NuhaMedika, 102.

Damayanti, I. P., Liva Maita, S. S. T., Ani Triana, S. S. T., \& Rita Afni, S. S. T. (2015). Buku Ajar: Asuhan Kebidanan Komprehensif Pada Ibu Bersalin dan Bayi Baru Lahir/oleh Ika Putri damayanti. Deepublish.

Farrer, H. (2001). Perawatan Maternitas (Maternity Care). Jakarta: Penerbit Buku Kedokteran EGC.
Heni Setyowati, E. R., \& Kp, S. (2018). Akupresur untuk Kesehatan Wanita Berbasis Hasil Penelitian. Unimma Press.

Mutmainah, A. U., Johan, H., \& Llyod, S. S. (2017). Asuhan Persalinan Normal \& Bayi Baru Lahir. Yogyakarta: ANDI.

Rehatta NM, dkk. (2019). Anestesiologi dan Terapi Intensif: Buku Teks Kati-Perdatin. Jakarta: Gramedia Pustaka Utama

Saleh, L. M. (2019). Teknik Relaksasi Otot Progresif Pada Air Traffic Controller (ATC). Deepublish.

Simkin, P., Whalley, J., \& Keppler, A. (2010). Panduan Lengkap Kehamilan, Melahirkan, \& Bayi (Edisi Revisi). Jakarta: Arcan.

Sugiono, S. (2016). Metode Penelitian Kuantitatif, Kualitatif, dan R \& D.

Sunarsih, S., \&Ernawati, E. (2017). PerdedaanTerapi Massage dan Terapi Relaksasi dalam Mengurangi Nyeri Persalinan di BidanPraktikSwasta (BPS) Ernawati Kecamatan Banyumas. Jurnal Kesehatan, 8(1), 8-12.

Widiastini, L. P. (2018). Buku Ajar Asuhan Kebidanan Pada Ibu Bersalin Dan Bayi Baru Lahir. In Media. 